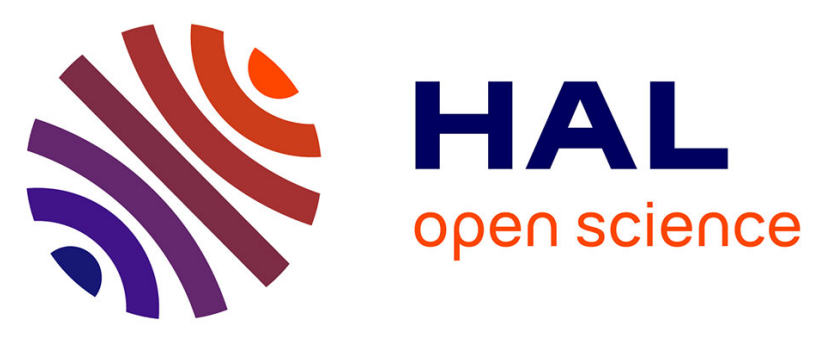

\title{
Parentage assignment in the critically endangered European sturgeon (Acipenser sturio) based on a novel microsatellite multiplex assay: a valuable resource for restocking, monitoring and conservation programs
}

Séverine Roques, Patrick Berrebi, Patrick Chèvre, Eric Rochard, Marie-Laure

Acolas

\section{To cite this version:}

Séverine Roques, Patrick Berrebi, Patrick Chèvre, Eric Rochard, Marie-Laure Acolas. Parentage assignment in the critically endangered European sturgeon (Acipenser sturio) based on a novel microsatellite multiplex assay: a valuable resource for restocking, monitoring and conservation programs. Conservation Genetics Resources, 2016, 8 (3), pp.313-322. 10.1007/s12686-016-0538-7 . hal01709796

\author{
HAL Id: hal-01709796 \\ https://hal.science/hal-01709796
}

Submitted on 15 Feb 2018

HAL is a multi-disciplinary open access archive for the deposit and dissemination of scientific research documents, whether they are published or not. The documents may come from teaching and research institutions in France or abroad, or from public or private research centers.
L'archive ouverte pluridisciplinaire HAL, est destinée au dépôt et à la diffusion de documents scientifiques de niveau recherche, publiés ou non, émanant des établissements d'enseignement et de recherche français ou étrangers, des laboratoires publics ou privés. 
1 Parentage assignment in the critically endangered European

2 sturgeon (Acipenser sturio) based on a novel microsatellite multiplex assay: a valuable resource for restocking, monitoring and conservation programs

${ }^{1}$ IRSTEA, EABX, 50 avenue de Verdun, 33612 Cestas Cedex, France.

2 UMR 5554, Institut des Sciences de I'Evolution, Université de Montpellier, CNRS, IRD, EPHE, CC 065. 
27 SUMMARY: The only remaining population of the critically endangered European sturgeon, Acipenser sturio, is located in the Gironde basin (France). A restoration program initiated 20 years ago has allowed more than one and a half million individuals to be stocked. Effective monitoring of this population is a key prerequisite in ensuring the sustainability of this species in the wild. We report the development of a novel microsatellite multiplex assay for genetic monitoring of $A$. sturio. Diversity of a set of 18 loci was low to moderate, with a number of alleles and observed heterozygosity ranging from 4 to 7 and 0.33 to 0.74 respectively, depending on markers. A set of captive-born progeny of known relatives $(n=72)$ was used to examine the efficiency of this assay in assigning parentage to offspring. Three different programs were used. Correct assignment success was generally high (above 90\%), but differed between programs. Parentage analysis of individuals captured in the Gironde estuary ( $n=193$ ) demonstrated that most offspring (91.2\%) are unambiguously allocated to parent pairs from the broodstock. Our research provides an efficient and accurate method for the genetic monitoring of the restocking program, but also for others aspects of conservation, including genetic diversity evaluation, effective population size estimation, and inbreeding assessment. 


\section{INTRODUCTION}

Sturgeons are among the most threatened groups of fish in the world, with most species at risk of extinction (Rochard et al. 1990, Birstein 1993 and IUCN 2015). Because of some life characteristics (late age at maturity, diadromous life cycle for some species), the conservation of many sturgeon species has relied on long-term breeding and restocking programs - generally over several decades (Carmona et al. 2011, Williot 2011). The genetic monitoring of such species, also characterized by a large number of progeny, therefore depends upon time and cost-effective protocols for routine screening. There is currently a captive breeding stock of European sturgeon (Acipenser sturio) located at the Irstea experimental station in Saint-Seurin-sur-l'Isle, France. This stock, first created in 1994, is made up of wild-born adults and juveniles. Its aim is to secure the survival of the species and provide a basis for subsequent releases into the wild (Williot et al. 2007).

The first individuals from this stock were released back into the wild in 1995 (Williot et al. 2002) with further releases taking place 12 years later. Since then, more than one and a half million larvae and juveniles have been released into the Gironde basin. One priority of the restoration program is to characterize the estuarine portion of the population and estimate the efficiency of restocking by monitoring the population in the Gironde estuary (Rochard et al. 2001, Lochet et al. 2004, Acolas et al. 2011). Because the probability of A. sturio reproduction in the wild has been low since 1994, an almost closed system is expected, in which most of the captured individuals would belong to the captive-born stock. Since 2007, restocking plans have been devised whereby the progeny of unique parent pairs that are released into the wild at different stages (i.e. larvae, juvenile) and in different locations (Gironde, Dordogne) can be identified. This plan also allows the survival of these different offspring to be assessed based on these criteria. The development of genetic tagging is necessary to provide unambiguous identification of supplemental fish, and to evaluate survival and/or reproductive success in A. sturio. 
Of the many different methods used for fish tagging, genetic monitoring would appear to be the most efficient for young stages. This is because it is not constrained by issues of size, as is the case with transponders and external devices (Feldheim et al. 2002, DeHaan et al. 2007). It also has an advantage over mass chemical markers, the effectiveness of which are also reduced when applied to very young sturgeons (Lochet et al. 2011).

Genetic tagging using microsatellites consists of creating a genetic profile for each captured individual, allowing them to be assigned to a given population or parental pair (Lukacs \& Burnham 2005). This approach is popular in the management of conservation programs involving aquatic organisms (Hansen et al. 2001, Liu \& Cordes 2004, Moghim et al. 2013, Abdul-Muneer 2014). For example, it is often used to analyze the proportion of wild-born individuals and captive-born individuals in the natural environment (Poteaux et al. 1999, Bravington \& Ward 2004, Meraner et al. 2014). Microsatellite markers are also powerful tools in captive management (O'Reilly \& Kozfkay 2014) because they enable the genetic characterization of captive broodstock (Koljonen et al. 2002, Machado-Schiaffino et al. 2007, Cooper et al. 2009), as well as guiding mating strategies based on relatedness (Kozfkay et al. 2007, Nielsen et al. 2007, O'Reilly \& Kozfkay 2014), inbreeding levels (Borrell et al. 2007), and breeding success (e.g., McLean et al. 2007, Hoskin et al. 2015, Sard et al. 2015).

The number of markers needed to obtain reliable results will depend upon the genetic variability of the species studied and the taxonomic level or geographic scale of the analysis required (Frankham et al. 2002, Wan et al. 2004). Restocking and conservation programs generally focus on species characterized by population declines and low genetic diversity. Relatively large numbers of microsatellites are often necessary to gain sufficient reliability and statistical power. Multiplex assays (i.e. the amplification of several microsatellite loci in single PCRs) are therefore relevant for the development of standardized screening protocols for cost-effective genetic analyses (Neff et al. 2000, Renshaw et al. 2006, Morvezen et al. 2013, Panagiotopoulou et al. 2014). Numerous microsatellites have already been developed and used to study wild and captive populations of sturgeon species, for conservation or in commercial breeding programs (May et al. 1997, McQuown et al. 2000, King et al. 2001, 
Henderson-Arzapalo \& King 2002, Zane et al. 2002, Welsh et al. 2003, Zhu et al. 2005, Börk et al. 2007, Forlani et al. 2007, Fopp-Bayat \& Woznicki 2008, Waldman et al. 2008, Dudu et al. 2011, Moghim et al. 2012, Wozney et al. 2012, Moghim et al. 2013, Zeng et al. 2013, Georgescu et al. 2014, Liu et al. 2014, Panagiotopoulou et al. 2014, Wirgin et al. 2015).

For A. sturio, there are currently no available specific markers and no standardized multiplex protocols. Only a handful of preliminary studies have described species diversity based on non-specific (Ludwig et al. 2004, Ludwig 2005, Williot et al. 2007, Chassaing 2010, Berrebi \& Cherbonnel 2011, Chassaing et al. 2011) or unpublished (Tiedemann et al. 2011) markers. One of the characteristics of the last remaining population of this species is its low genetic diversity (Chassaing 2010), which makes it difficult to design reliable protocols with sufficient resolution power.

In this paper, we present a method based on three multiplexes totaling 18 polymorphic microsatellite loci for its use in the conservation and restocking programs of $A$. sturio. Specifically, the aims of the present study were to (1) Develop and validate an optimized multiplex protocol as a standard genotyping tool for individual genetic tagging (2) Test our assay on 193 individuals captured in the Gironde Estuary (South West of France) in order to assess the feasibility of our methodology in real monitoring condition, and (3) Discuss the usefulness of our assay for the genetic monitoring of both the captive breeding and restocking programs for the long term management of the species.

\section{MATERIALS AND METHODS}

\section{Biological material and DNA extraction}

We sampled a total of 109 A. sturio from the captive broodstock (BROODSTOCK) ( $N=19$ males and 18 females) composed of 33 wild adults and juveniles captured during the 19701994 period and 4 adults from the first cohort born in captivity in 1995, and 72 captive progeny (FARM) issued from 30 known parents for the validation of parentage testing. Additionally, 193 individuals, obtained by trawling in the Gironde estuary (Aquitaine, France) during population monitoring campaigns (2009-2014) were sampled (CAPTURED) (Acolas et 
Author-produced version of the article published in Conservation Genetics Resources, 2016, 8, 313-322 The original publication is available at http://link.springer.com

doi : 10.1007/s12686-016-0538-7

al. 2011). These captured individuals (juveniles and adults of length between $40-130 \mathrm{~cm}$; mean $=70 \mathrm{~cm}$ ) may come either from captive cohorts of the restocking program that involve a total of 27 known mating pairs between 2007 and 2014, or from reproduction events in the wild. For all individuals, a piece of fin was individually collected and preserved in 95\% ethanol.

\section{Selection and test of sturgeon microsatellites in A. sturio}

DNA extraction was performed using the Chelex extraction method (Walsh et al. 1991).

Because there were no available microsatellite markers specifically developed for $A$. sturio, a total of 118 microsatellite sequences developed for other sturgeon species were screened in the European sturgeon (see Appendix 1). Firstly, simplex PCR amplifications were tested on 24 individuals in a $25 \mu \mathrm{L}$ reaction volume composed of 0.5 units of Promega Taq polymerase, $1.5 \mathrm{mM} \mathrm{MgCl} 2,0.2 \mathrm{mM}$ of each deoxyribonucleotide, $1 \mathrm{X}$ buffer and $12.5 \mathrm{pmol}$ of each primer. PCR was performed for all loci with the following thermocycling regime: $95^{\circ} \mathrm{C}$ for 5 min, then $\left(95^{\circ} \mathrm{C} 40 \mathrm{~s}, 54{ }^{\circ} \mathrm{C} 40 \mathrm{~s}\right.$ and $\left.72{ }^{\circ} \mathrm{C} 40 \mathrm{~s}\right) \times 34$ cycles, and $72{ }^{\circ} \mathrm{C}$ for $10 \mathrm{~min}$. Amplification success was checked by running PCR products on an agarose gel. Loci which successfully amplified were then tested with the same PCR conditions. Forward primers were labelled with a fluorescent dye (6-FAM ${ }^{\mathrm{TM}}, \mathrm{Cy} 3, \mathrm{NED}^{\mathrm{TM}}$ or TET) in simplex or duplex reactions. The PCR products were separated on a denaturing $6 \%$ polyacrylamide gel and then scanned on a fluorescence image analyzer, FMBIO II Multi-View (Hitachi Software, Tokyo, Japan). A total of 34 loci (see Supplementary material S1) were selected and tested in Multiplex reactions on 24 individuals. PCR amplifications were carried out with the Type-it Microsatellite PCR Kit (Qiagen $^{\mathrm{TM}}$ ) in a $10.5 \mu$ l reaction volume containing $6.25 \mu$ l of Type-it Multiplex PCR Master Mix, $1.25 \mu \mathrm{l}$ primer mix (each primer at $2 \mu \mathrm{M}$ ) with forward primers labelled at $5^{\prime}$ end using fluorescent dyes (6-FAM ${ }^{\mathrm{TM}}, \mathrm{HEX}^{\mathrm{TM}}$ and $\mathrm{NED}^{\mathrm{TM}}$ ), $3 \mu \mathrm{l}$ RNase-free water and $4 \mu \mathrm{l}$ Chelex DNA extraction. Thermal cycling profile followed manufacturer conditions (Qiagen ${ }^{\mathrm{TM}}$ ) and PCR products were separated on a capillary sequencer (either $A B I 3130 \mathrm{XL}$ or $A B I 3500 \mathrm{XL}$, Applied Biosystem ${ }^{\mathrm{TM}}$ ). Fragment lengths were assessed with Peak Scanner v1.0 and GeneMapper v4.0 softwares (Life Technologies ${ }^{\mathrm{TM}}$ ). Selection of the best quality markers was done first, discarding those with more than two alleles per individual or with very low variability. To reduce the probability of genotyping errors, we prioritized those with high 
Author-produced version of the article published in Conservation Genetics Resources, 2016, 8, 313-322 The original publication is available at http://link.springer.com

doi : 10.1007/s12686-016-0538-7

162

163

164

165

166

167

168

169

170

171

172

173

174

175

176

177

178

179

180

181

182

183

184

185

186

187

188

189

190

191

reliability, clear patterns of the expected range, and high signal intensity. The remaining 18 loci were amplified in three multiplex (MLPX1, MLPX2 and MLPX3; see Table 1).

\section{Statistical analysis and optimization of a microsatellite multiplex assay}

Basic genetic parameters including allele frequencies, numbers of alleles per locus (A) and observed (Ho) and expected (He) heterozygosity were calculated for BROODSTOCK individuals using CERVUS v.3.0 (Kalinowski et al. 2007). Linkage disequilibrium between pairs of loci was tested with GENEPOP 4.0 (Rousset 2008) using the Markov chain method (10 000 dememorization steps, 100 batches, 5000 iterations) and Fisher's exact test; a sequential Bonferroni correction for multiple testing was applied (Rice 1989). Null allele frequency estimates were computed using CERVUS 3.0. The success of amplification was calculated as the percentage of positive PCR for each locus over the whole sample. The 18 selected loci were classified in increasing order of probability of identity (PID) (Waits et al. 2001) which is a good predictor of the true probability of correct parentage assignment. PID values were calculated using the GIMLET software (Valière 2002) under "sibs" and "unrelated" relatedness scenarios. The polymorphic information Content (PIC) for each locus, as well as the combined non-exclusion probabilities over loci, for first parent (NE-1P), second one (NE2P), parent pair (NE-PP), unrelated individuals (NE-unrel) or siblings (NE-sibs) were calculated using CERVUS v.3.0 (Kalinowski et al. 2007).

\section{Parentage testing and applicability for the restocking program}

To validate the best parentage assignment protocol, our microsatellite multiplex assay was first tested on 72 progeny of known parents (FARM) with three commonly used programs that perform different algorithms: CERVUS v3.0 (Marshall et al. 1998, Kalinowski et al. 2007); PASOS v1.0 (Duchesne et al. 2005) and PAPA 2.0 (Duchesne et al. 2002). CERVUS and PASOS allow for incomplete parental sampling (i.e. open systems) while PAPA is better designed for parentage assignment in closed systems (i.e. all parents are sampled). To select the minimum number of loci necessary for reliable assignment, all three programs were tested using several sets of an increasing number of markers, classified in the order of PID values.

CERVUS uses a likelihood-based approach to assign parental origin combined with simulation of parentage analysis to determine the confidence of parentage assignments. Likelihood 
score ratios (LOD or Delta) estimate the likelihood that the candidate parent is the true parent divided by the likelihood that the candidate parent is not the true parent. Before proceeding to the parentage assignment, simulations were run in CERVUS to determine the distribution of the critical values of Delta or LOD score for $80 \%$ and $95 \%$ confidence levels. The following simulation parameters for 100,000 offspring were chosen for our studied organism: numbers of candidate parents (BROODSTOCK) incremented by a $10-15 \%$ corresponding to putative non-sampled parents (i.e. 20 candidate mothers and 22 candidate fathers), $10 \%$ of candidate parents with a relatedness coefficient of $0.1,98 \%$ of candidate parents sampled, $99 \%$ loci typed with a $1 \%$ error rate. Confidence levels obtained from simulations were used for true paternity screening of the 72 progeny (FARM). In PASOS and PAPA, likelihoods are calculated for each potential parental pair and the allocation of a descendant is based on the search for the most likely pair among all potential pairs of known parents. For the analysis with those two programs, we allowed one locus genotype mismatch between parents and offspring (i.e. offset $=1$ ) as suggested by the author ( $P$. Duchesne, Personal Communication). Assignments of FARM samples were compared to the true parent's pairs, which was defined as true assignment (i.e. TRUE). The difference between both assignments is considered as the error rate associated with the method. Assignment success, true assignment, and error rates were also compared among the three programs.

To test the feasibility of our assay in tracking the parental origins of cohorts released into the wild, parentage analysis was conducted on 193 individuals captured in the Gironde Estuary (CAPTURED).

\section{RESULTS}

\section{Microsatellite variability}

Of the 118 primer pairs tested, $80(68 \%)$ gave an amplification product, and among those, 33 (41\%) were polymorphic (i.e. two or more alleles per locus) (Appendix 1). To decrease the putative error rate associated with allele scoring, we decided to exclude 15 loci based on unclears signal on the capillary sequencer (AfuG113, AoxB34, AoxD241, AciG198, Afu19, and 
AoxD297), or low reliability (AfuG184, Ag16). Other seven markers were omitted because of their reduced variability (Afu54, Ag20, Aox23, Aox27, AoxD54, AS002, Spl101). Statistics for the 18 selected loci are given in Table 1. No overlapping of allele size ranges was observed within any of the three multiplexes and the amplification success was high for all loci (Table 1). No significant linkage disequilibrium was detected between pairs of markers after Bonferroni corrections. Overall polymorphism was moderate to low, with the number of alleles (Na) varying from two (Ag39) to seven (Ag10) alleles per locus, He from 0.46 to 0.90 and Ho from 0.33 to 0.74 . Null allele frequency was displayed for a single marker, but at a very low rate (AoxD188; $\leq 0.05$ ). PIC values varied between loci, between 0.37 and 0.77 . Although the mean number of alleles per locus was low $(n=4)$, the potential of these 18 loci used in combination to distinguish individuals was high, as indicated by the low cumulative probability of identity (PID) over loci of respectively of $5 \mathrm{E}-12$ or $1 \mathrm{E}-05$, assuming all individuals are unrelated (PID-unrel) or siblings (PID-sibs). Values of non-exclusion probabilities for unrelated (NE-unrel) and siblings (NE-sibs) were also low, at $1.18 \mathrm{E}-12$ and 4.62E-06, respectively, as well as the combined non-exclusion probabilities for the first parent, second parent and parent pairs of $1.6 \mathrm{E}-02,4.9 \mathrm{E}-05$ and $2.5 \mathrm{E}-06$, respectively. Amplification success was high for all loci (Table 1 ).

\section{Validation of parentage assignment in A. sturio}

Simulations in CERVUS result in high assignment rates, with $98 \%$ assignments of parent pairs at both strict $(95 \%)$ and relaxed (80\%) levels. Only $2 \%$ of simulated offspring remained unassigned. Individual genetic tagging was successful in identifying the parental origins of most individuals originating from the breeding program (FARM). The parentage assignments of these offspring using the three methods (CERVUS, PASOS, and PAPA) are shown in Figure 1. Overall, assignment success was high and increased as the number of loci used went up, but for all programs the highest level of assignment success was obtained for 17 loci (Figure 1A). For FARM, parentage analysis using CERVUS generated $100 \%$ parent pair assignments (Figure 1B). The results of assignment tests in CERVUS showed that most individuals (95.8\%) were assigned to the parent pair matching the parent database information (i.e. named TRUE assignment) at high (strict, 95\%) or lower (relaxed, 80\%) level of confidence, but that a few individuals ( $\mathrm{N}=3$ out of $72,4.2 \%$ ) were wrongly assigned. Using PASOS, $93.1 \%$ of offspring were unambiguously assigned to their true parents ( $N=67$ out of 72 ), while four 
Author-produced version of the article published in Conservation Genetics Resources, 2016, 8, 313-322

(5.5\%) had a parentage assignment corresponding to "uncollected" mother or father (Duchesne et al. 2005) and one was assigned to wrong parental pair (i.e. 1.4\%). PAPA gave 65 correct assignments (90.3\%) ( $\mathrm{N}=65$ out of 72$)$ and 2 wrong assignments $(2.7 \%)$, while the assignment of the remaining individuals was ambiguous (i.e. the highest likelihood is shared by several parental pairs, see Duchesne et al. 2002), and is therefore the least powerful program in parentage testing for $A$. sturio. These results indicate that error rates associated with the methodology (i.e. the difference between assignment and TRUE assignment) are low to moderate and range from $9.7 \%$ to $4.2 \%$, depending on the program used.

\section{Genetic monitoring of the stocked population}

The results of analyses of the captured individuals (CAPTURED, $\mathrm{N}=193$ ) were compared between CERVUS and PASOS, the two most powerful programs. Parentage testing of CAPTURED using CERVUS generated $99 \%$ parent pair assignments. A single juvenile was not assigned with a sufficient level of confidence ( $<80 \%$ confidence). Using PASOS, assignment success for parent pairs was $96 \%$. Eight individuals were assigned to one unsampled father or mother. When successful assignments were compared to the 23 known mating pairs from the breeding program, 17 individuals (8.8\%) and 18 individuals (9.3\%) were assigned to nonexisting parental pairs, for CERVUS and PASOS, respectively. Among those, 15 individuals were common among both programs. These 15 assignments $(7.8 \%)$ might be the result of errors associated with the method (estimated above between $6.9 \%$ and $4.2 \%$ ), as well as a possible wild origin.

\section{DISCUSSION}

Parentage assignment in endangered species - which are generally genetically impoverished - calls for a difficult balance to be struck between having enough polymorphic markers to provide the necessary resolution power and managing the time and expense associated with prolonged laboratory work (Harrison et al. 2013). In this study, we aimed to test and estimate a minimum number of loci for accurate parental assignment in A. sturio and optimize a multiplexing approach for routine screening. Because no specific markers were available for the species, we tested more than a hundred markers developed for other sturgeon species (i.e. "crosspriming"). We found that more than $40 \%$ of the markers were 
Author-produced version of the article published in Conservation Genetics Resources, 2016, 8, 313-322

polymorphic and that successful crosspriming concerned markers developed for either very close (i.e. A. oxyrinchus) or more distant (A. gueldenstaedtii) species (Appendix 1). Crosspriming has proved to be effective among sturgeon species (Rajkov et al. 2014) and its use has been largely extended in previous studies (May et al. 1997, King et al. 2001, Moghim et al. 2012).

Assignment success with microsatellites also relies on accurate genotyping. The high mutation rate of microsatellites is often associated with scoring errors (Pompanon et al. 2005), as well as frequent mismatches of offspring genotypes with those of their parents, which may lead to incorrect assignment and this will even increase while increasing the number of markers used. Generally, the number of typed loci should be chosen as a compromise between the probability of identity (more resolution) and the probability of error (loss of correct assignment). This stresses the need for the technique to be optimized and validated prior to its application to ensure accuracy in parent-offspring assignments (Nielsen et al. 2001). Although our results support the previous documented low genetic diversity for A. sturio (Chassaing et al. 2010, 2016), the final optimized assay of three multiplexes allowed efficient and reliable amplification of 18 loci with PID and non-exclusion probabilities sufficiently low to assure proper individual and parental identification. Our multiplex assay was successful in identifying the parents of a set of 72 progeny, whose parental origin was known (Figure 1). The analysis of cumulative loci revealed that 17 loci of the 18 were required in order to meet the maximum assignment rate. This has been observed elsewhere for individual assignment (Roques et al. 1999) and illustrates that adding extra loci may increase the proportion of erroneous genotypes, thus leading to a larger proportion of incorrect allocations. This also pointed out that Aox45 might be a poorly segregating locus. Considering the best assignment obtained with CERVUS, only three individuals were assigned to the wrong parental pairs (i.e. $4.2 \%$ ), which is a satisfying result given the very low genetic diversity of the species, some level of relatedness among parents and the high probability of scoring errors. This value could be considered the maximum error rate associated with the present genetic assay (i.e. corresponding to laboratory, sample handling, or data transcription's errors) and should be taken into account in future analyses. These results support the potential of these programs to establish parent-offspring 
relationships even when some genotypes are incomplete, incorrect or missing (Kalinowski et al. 2007).

This study further clearly highlights the power of this multiplex assay for the monitoring of the $A$. sturio restocking program. Genetic tagging proved to be a reliable tool for species conservation programs requiring a high number of individuals to be monitored (Andreou et al. 2012). For A. sturio population monitoring, tagging systems such as PIT (passive integrated transponder) or WOT tags (external loop tags, wire on tag) are efficient methods, but are limited by the size of fish (Acolas et al. 2011). Genetic tagging clearly avoids the problem of tag loss, and can be used at all stages. Furthermore, genetic monitoring is a widely used tool to estimate successful reintroduction, establishment and reproduction of individuals released into the wild (e.g. Perrier et al. 2013, Sard et al. 2015, Schreier et al. 2015). Our results provide compelling evidence that most individuals captured in the Estuary descended from captive breeders (91.2\%) and thus give positive signs of reintroduction success of captive-born $A$. sturio into the wild. In addition, according to our previous error estimation (4.2\%) a small estimated proportion (i.e. 100-(91.2+4.2) $=4.6 \%$ corresponding to 9 individuals) might be issued from reproduction in the wild which need to be confirmed by further investigations. This indicates that $A$. sturio survival will depend mostly upon successful captive breeding and stocking, and stresses the importance of such genetic assay for the careful and intensive ex-situ management of this species.

Our genetic assay further enables the study of other aspects of genetic management such as monitoring levels of genetic variability in the captive stock, estimating inbreeding coefficients or breeding success. For example, the comparison of the genetic composition and levels of inbreeding between the captive stock and the released cohorts are important clues in conservation breeding programs (Wilson et al; 2012, Schreier et al. 2015). The captive breeding stock of $A$. sturio in Europe is shared through a joint conservation program between IRSTEA in Bordeaux and IGB (Institute of Freshwater Ecology and Inland Fisheries) in Berlin, and sturgeons from France are regularly transferred to be released into the Elbe and to complement the German captive stock in Germany (Kirschbaum et al. 2011). This set of multiplex assays has the potential to become a promising tool to standardize genetic information and coordinate scientific tools to assist in genetic management of $A$. sturio in the future. 


\section{ACKNOWLEDGEMENTS}

346

347

We wish to thank the regional funders of this study: Agence de l'Eau Adour Garonne, DREAL (Direction régionale de l'environnement, de l'aménagement et du logement ; Aquitaine), région Aquitaine, Conseil Régional Gironde. This study was also supported by the National French Action Plan in favor of $A$. sturio restoration. We thank Pierre Duchesne for help in assignment analyses using PASOS and PAPA programs, Frédérique Cerqueira and Erick Desmarais for their help in data acquisition. Data used in this work were (partly) produced through the Genotyping and Sequencing facilities of ISEM (Institut des Sciences de I'Evolution-Montpellier) and Labex Centre Méditerranéen Environnement Biodiversité. We also thank technicians from Migado association and from Irstea for fins sampling within the captive stock.

\section{FIGURES}

Figure 1. Comparison of assignment success (in percentage) of captive-born progeny (FARM) using three programs (PASOS, CERVUS, and PAPA). A) TRUE assignment rates for several sets of increasing number of markers (from 12 to 18 ) classified in increasing order of probability of identity (PID). TRUE refers to assignment success when compared to known data of parental pairs. B) Assignment, TRUE assignment and error rates for the multiplex assay of 17 markers.

\section{REFERENCES}

Abdul-Muneer PM (2014) Application of microsatellite markers in conservation genetics and fisheries management: recent advances in population structure analysis and conservation strategies. Genetics Res Int, 691-759.

Acolas ML, Roqueplo C, Rouleau E, Rochard E (2011) Chapter 29 - Post release monitoring techniques. In:Williot P, Rochard E, Desse-Berset N, Kirschbaum F, Gessner J (eds) Biology and conservation of the Atlantic European sturgeon Acipenser sturio L, 1758. Springer Berlin Heidelberg. pp. 407-416.

Andreou D, Vacquie-Garcia J, Cucherousset J, Blanchet S, Gozlan RE, Loot G (2012) Individual genetic tagging for teleosts: an empirical validation and a guideline for ecologists. J Fish Biol, 80, 181-194. 
Berrebi P, Cherbonnel C (2011) Analyse génotypique des géniteurs d'esturgeons Acipenser Sturio, en vue de croisements garantissant le maximum de diversité génétique aux descendants. Unpublished report. $11 \mathrm{p}$.

Birstein, V. J. (1993). "Sturgeons and paddlefishes: threatened fishes in need of conservation." Cons Biol, 7(4): 774-787.

Börk K, Drauch A, Israel JA, Pedroia J, Rodzen J, May B (2007) Development of new microsatellite primers for green and white sturgeon. Conserv Genet, 9, 973-979.

Borrell YJ, Carleos CE, Asturiano JF, Bernardo D, Vázquez E, Corral N, Sánchez JA, Blanco G (2007) Use of microsatellites and a combinatorial optimization approach in the acquisition of gilthead seabream (Sparus aurata L.) broodstocks for hatcheries. Aquaculture, 269, 200-210.

Bravington MV, Ward RD (2004) Microsatellite DNA markers: evaluating their potential for estimating the proportion of hatchery-reared offspring in a stock enhancement programme. Mol Ecol, 13, 1287-1297.

Carmona R, Domezain A, Garcia-Gallego M, Hernando JA, Rodriguez F, Ruiz-Rejón M (2011) Biology, Conservation and sustainable development of Sturgeons. Springer Science + business Media BV

Chassaing O (2010) Organisation génétique des populations d'esturgeon Européen, Acipenser sturio: passé, présent, futur. PhD dissertation, University of Montpellier, 491p.UNIVERSITE MONTPELLIER II

Chassaing O, Hanni C, Berrebi P (2011) Distinguishing species of European sturgeons Acipenser spp. using microsatellite allele sequences. J Fish Biol, 78, 208-226.

Chassaing O, Desse-Berset N, Hänni C, Hugues S, Berrebi P (2016). Phylogeography of the European sturgeon (Acipenser sturio): a critically endangered species. Mol Phylogenet Evol 94, 346-357.

Cooper AM, Miller LM, Kapuscinski AR (2009) Conservation of population structure and genetic diversity under captive breeding of remnant coaster brook trout (Salvelinus fontinalis) populations. Cons Gen, 11, 1087-1093.

DeHaan PW, Jordan GR, Ardren WR (2007) Use of genetic tags to identify captive-bred pallid sturgeon (Scaphirhynchus albus) in the wild: improving abundance estimates for an endangered species. Cons Gen, 9, 691-697. 
Duchesne P, Castric T, Bernatchez L (2005) PASOS (parental allocation of singles in open systems): a computer program for individual parental allocation with missing parents. Mol Ecol Notes, 5, 701704.

Duchesne P, Godbout MH, Bernatchez L (2002) PAPA (package for the analysis of parental allocation): a computer program for simulated and real parental allocation. Mol Ecol Notes, 2, 191-193.

Duchesne P, Meldgaard T, Berrebi P (2008). Parentage analysis with few contributing breeders: validation and improvement. J Hered, 99(3), 323-334.

Dudu A, Suciu R, Paraschiv M, Georgescu SE, Costache M, Berrebi P (2011) Nuclear markers of Danube Sturgeons hybridization. Int J Mol Sci, 12, 6796-6809.

Feldheim KA, Gruber SH, de Marignac JRC, Ashley MV (2002) Genetic tagging to determine passive integrated transponder tag loss in lemon sharks. J Fish Biol, 61, 1309-1313.

Fopp-Bayat D, Woznicki P (2008) Test of Mendelian segregation among 10 microsatellite loci in the fourth generation of bester (Huso husoL. $\times$ Acipenser ruthenus L.). Aquac Res, 39, 1377-1382.

Forlani A, Fontana F, Congiu L (2007) Isolation of microsatellite loci from the endemic and endangered Adriatic sturgeon (Acipenser naccarii). Conserv Genet, 9, 461-463.

Frankham, R., Ballou, J. D., Briscoe, D. A. (2002) Introduction to Conservation Genetics, Cambridge University Press, New York.

Georgescu SE BA, Florescu I, Popa OG, Dudu A CM (2014) Microsatellite Variation in Russian Sturgeon (Acipenser gueldenstaedtii) from Aquaculture. Anim Sci Biotechnol, 47, 73-76.

Hansen M, Kenchington E, Nielsen E (2001) Assigning individual fish to populations using microsatellite DNA markers. Fish Fish, 2, 93-112.

Harrison HB, Saenz-Agudelo P, Planes S, Jones GP, Berumen ML (2013) Relative accuracy of three common methods of parentage analysis in natural populations. Mol Ecol, 22, 1158-1170.

Henderson-Arzapalo A, King TL (2002) Novel microsatellite markers for Atlantic sturgeon (Acipenser oxyrinchus) population delineation and broodstock management. Mol Ecol Notes, 2, 437-439.

Hoskin ML, Hutchison MJ, Barnes AC, Ovenden JR, Pope LC (2015) Parental contribution to progeny during experimental spawning of jungle perch, Kuhlia rupestris. Mar Freshwater Res, 66, 375. 
IUCN (2015) The IUCN red list of threatened species. Version 2015-4. In. www.iucnredlist.org Accessed 20 January 2016

Jay K, Crossman JA, Scribner KT (2014) Estimates of Effective Number of Breeding Adults and Reproductive Success for White Sturgeon. T Am Fish Soc, 143, 1204-1216.

Kalinowski ST, Taper ML, Marshall TC (2007) Revising how the computer program CERVUS accommodates genotyping error increases success in paternity assignment. Mol Ecol, 16, 10991106.

King TL, Lubinski BA, Spidle AP (2001) Microsatellite DNA variation in Atlantic sturgeon (Acipenser oxyrinchus oxyrinchus) and cross-species amplification in the Acipenseridae. Conserv Genet, 2, 103-119.

Kirschbaum F, Williot P, Fredrich F, Tiedemann R, Gessner J (2011) Restoration of the European Sturgeon Acipenser sturio in Germany. In: Williot P, Rochard E, Desse-Berset N, Kirschbaum F, Gessner J (eds) Biology and conservation of the Atlantic European sturgeon Acipenser sturio L, 1758. Springer Berlin Heidelberg. pp. 309-333.

Koljonen M, Tahtinen J, Saissa M, Koskiniemi J (2002) Maintenance of genetic diversity of Atlantic salmon (Salmo salar) by captive breeding programs and the geographic distribution of microsatellite variation. Aquaculture, 212, 69-92.

Kozfkay CC, Campbell MR, Heindel JA, Baker DJ, Kline P, Powell MS, Flagg T (2007) A genetic evaluation of relatedness for broodstock management of captive, endangered Snake River sockeye salmon, Oncorhynchus nerka. Conserv Genet, 9, 1421-1430.

Liu ZJ, Cordes JF (2004) DNA marker technologies and their applications in aquaculture genetics. Aquaculture, 238, 1-37.

Liu Y, Li C, Cheng L, Lu CY, Sun XW (2014) Development and characterization of new microsatellite markers for Amur sturgeon (Acipenser schrenckii). Conserv Genet Res, 6, 65-67.

Lochet A, Lambert P, Lepage M, Rochard E (2004) Growth comparison between wild and hatcheryreared juvenile European sturgeons Acipenser sturio (Acipenseridae) during their stay in the Gironde estuary (France). Cybium, 28, 91-98.

Lochet A, Jatteau P, Gessner J (2011) Detection of chemical marks for stocking purposes in sturgeon species. J App Ichthyol, 27, 444-449. 
Ludwig A, Williot P, Kirschbaum F, Lieckfeld D (2004) Genetic Variability of the Gironde population of Acipenser sturio. Bundesamt für Naturschutz 101, 54-72.

Ludwig A (2005) A sturgeon view on conservation genetics. Eur J Wildlife Res, 52, 3-8.

Lukacs P, Burnham K (2005) Review of capture-recapture methods applicable to noninvasive genetic sampling. Mol Ecol, 14, 3909-3919.

Machado-Schiaffino G, Dopico E, Garcia-Vazquez E (2007) Genetic variation losses in Atlantic salmon stocks created for supportive breeding. Aquaculture, 264, 59-65.

Marshall T, J S, LEB K, JM P (1998) Statistical confidence for likelihood-based paternity inference in natural populations. Mol Ecol, 7, 639-655.

May B, Krueger CC, Kincaid HL (1997) Genetic variation at microsatellite loci in sturgeon: primer sequence homology in Acipenser and Scaphirhynchus. Can J Fish Aquat Sci, 54, 1542-1547.

McLean JE, Seamons TR, Dauer MB, Bentzen P, Quinn TP (2007) Variation in reproductive success and effective number of breeders in a hatchery population of steelhead trout (Oncorhynchus mykiss): examination by microsatellite-based parentage analysis. Conserv Genet, 9, 295-304.

McQuown EC, Sloss BL, Sheehan RJ, Rodzen J, Tranah GJ, May B (2000) Microsatellite analysis of genetic variation in sturgeon: New primer sequences for Scaphirhynchus and Acipenser. T Am Fish Soc, $129,1380-1388$.

Meraner A, Cornetti L, Gandolfi A (2014) Defining conservation units in a stocking-induced genetic melting pot: unraveling native and multiple exotic genetic imprints of recent and historical secondary contact in Adriatic grayling. Ecol Evol, 4, 1313-1327.

Moghim M, Heist EJ, Tan SG, Pourkazemi M, Siraj SS, Panandam JM, Pourgholam R, Kor D, Laloei F, Taghavi MJ (2012) Isolation and characterization of microsatellite loci in the Persian sturgeon (Acipenser persicus, Borodine, 1897) and cross-species amplification in four commercial sturgeons from the Caspian Sea. Iran J Fish Sci, 11, 548-558.

Moghim M, Javanmard A, Pourkazemi M, Tan SG, Panandam JM, Kor D, Laloei F (2013) Application of microsatellite markers for genetic conservation and management of Persian sturgeon (Acipenser persicus, Borodin, 1897) in the Caspian Sea. J App Ichthyol, 29, 696-703.

Neff BD, Fu P, Gross MR (2000) Microsatellite Multiplexing in Fish. T Am Fish Soc, 129, 584-593. 
Nielsen R, Mattila D, Clapham P, Palsboll P (2001) Statistical approaches to paternity analysis in natural populations and applications to the North Atlantic humpback whale. Genetics, 157, 16731682.

Nielsen RK, Pertoldi C, Loeschcke V (2007) Genetic evaluation of the captive breeding program of the Persian wild ass. J Zool, 272, 349-357.

O'Reilly PT, Kozfkay CC (2014) Use of microsatellite data and pedigree information in the genetic management of two long-term salmon conservation programs. Rev Fish Biol Fisher, 24, 819-848.

Panagiotopoulou H, Popovic D, Zalewska K, Weglenski P, Stankovic A (2014) Microsatellite multiplex assay for the analysis of Atlantic sturgeon populations. J Appl Genet. 10.1007/s13353-014-0216-y

Perrier C, Bagliniere JL, Evanno G (2013a) Understanding admixture patterns in supplemented populations: a case study combining molecular analyses and temporally explicit simulations in Atlantic salmon. Evol Appli, 6, 218-230.

Perrier C, Guyomard R, Bagliniere JL, Nikolic N, Evanno G (2013b) Changes in the genetic structure of Atlantic salmon populations over four decades reveal substantial impacts of stocking and potential resiliency. Ecol Evol, 3, 2334-2349.

Pompanon F, Bonin A, Bellemain E, Taberlet P (2005) Genotyping errors: causes, consequences and solutions. Nat Rev Genet, 6, 847-859.

Poteaux C, Bonhomme P, Berrebi P (1999) Microsatellite polymorphism and genetic impact of restocking in Mediterranean brown trout (Salmo trutta L.). Heredity, 82, 645-653.

Rajkov J, Shao Z, Berrebi P (2014) Evolution of Polyploidy and Functional Diploidization in Sturgeons: Microsatellite Analysis in 10 Sturgeon Species. J Hered. 105, 521-531.

Renshaw MA, Saillant E, Bradfield SC, Gold JR (2006) Microsatellite multiplex panels for genetic studies of three species of marine fishes: red drum (Sciaenops ocellatus), red snapper (Lutjanus campechanus), and cobia (Rachycentron canadum). Aquaculture, 253, 731-735.

Rice W (1989) Analyzing tables of statistical tests. Evolution, 43, 223-225.

Rochard E, Castelnaud G, Lepage M (1990) Sturgeons (Pisces: Acipenseridae); threats and prospects. J Fish Biol, 37, 123-132.

Rochard E, Lepage M, Dumont P, Tremblay S, Gazeau C (2001) Downstream migration of juvenile European sturgeon Acipenser sturio L. in the Gironde Estuary. Estuaries, 24, 108-115. 
Roques S, Duchesne P, Bernatchez L (1999) Potential of microsatellites for individual assignment: the North Atlantic redfish (genus Sebastes) species complex as a case study. Mol Ecol 8, 1703-1717.

Rousset F (2008) Genepop'007: a complete reimplementation of the Genepop software for windows and Linux. Mol Ecol Res, 8, 103-106.

Sambrook J, Fritsch EF, Maniatis T (1989) Molecular Cloning: A Laboratory Manual., Plainview, NY.

Sandu C, Reinartz R, Bloesch J (2013) Sturgeon 2020: A program for the protection and rehabilitation of Danube sturgeons. Danube Sturgeon Task Force (DSTF) \& EU Strategy for the Danube River (EUSDR) Priority Area (PA) 6 - Biodiversity.

Sard NM, O'Malley KG, Jacobson DP, Hogansen MJ, Johnson MA, Banks MA, Krkošek M (2015) Factors influencing spawner success in a spring Chinook salmon (Oncorhynchus tshawytscha) reintroduction program. Can J Fish Aquat Sci, 72, 1390-1397.

Schreier A, Stephenson S, Rust P, Young S (2015) The case of the endangered Kootenai River white sturgeon (Acipenser transmontanus) highlights the importance of post-release genetic monitoring in captive and supportive breeding programs. Biol Cons, 192, 74-81.

Tiedemann R, Schneider A, Williot P, Kirschbaum F (2011) Chapter 34: Genetic variability of cultured European sturgeon, Acipenser sturio. In: Springer (ed) Biology and conservation of the Atlantic European sturgeon Acipenser sturio. pp. 455-464.

Valière N (2002) GIMLET, a computer program for analysing genetic individual identification data. Mol Ecol Notes, 2, 377-379.

Valière N, Bonenfant C, Toïgo C, Luikart G, Gaillard J-M, Klein F (2007) Importance of a pilot study for non-invasive genetic sampling: genotyping errors and population size estimation in red deer. Conserv Genet, 8, 69-78.

Waits L, Luikart G, Taberlet P (2001) Estimating the probability of identity among genotypes in natural populations: cautions and guidelines. Mol Ecol, 10, 249-256.

Waldman JR, Doukakis P, Wirgin I (2008) Molecular analysis as a conservation tool for monitoring the trade of North American sturgeons and paddlefish. J Appl Ichthyol, 24, 20-28.

Walsh P, Metzger D, Higuchi R (1991) Chelex 100 as a Medium for Simple Extraction of DNA for PCRBased Typing from Forensic Material. Biotechniques, 10, 506-513. 
Wan QH, Wu H, Fujihara T, Fang SG (2004) Which genetic marker for which conservation genetics issue? Electrophoresis, 25, 2165-2176.

Welsh AB, Blumberg M, May B (2003) Identification of microsatellite loci in lake sturgeon, Acipenser fulvescens, and their variability in green sturgeon, A.medirostris. Mol Ecol Notes, 3, 47-55.

Williot P, Rochard, E., Desse-Berset, N., Kirschbaum, F. and Gessner, J. (Eds.). (2011) Biology and Conservation of the European Sturgeon Acipenser sturio L. 1758. The Reunion of the European and Atlantic Sturgeons.

Williot P, Rouault T, Brun R, Pelard M, Mercier D (2002) Status of caught wild spawners and propagation of the endangered sturgeon Acipenser sturio in France: a synthesis. Int Rev Hydrobiol, 87, 515-524.

Williot P, Rouault T, Pelard M, Mercier D, Lepage M, Davail-Cuisset B, Kirschbaum F, Ludwig A (2007) Building a broodstock of the critically endangered sturgeon Acipenser sturio: Problems and observations associated with the adaptation of wild-caught fish to hatchery conditions. Cybium, 31, 3-11.

Wilson CD, Beatty GE, Bradley CR, Clarke HC, Preston SJ, Roberts D and Provan J (2012) The importance of population genetic information in formulating ex situ conservation strategies for the freshwater pearl mussel (Margaritifera margaritifera L.) in Northern Ireland. Animal Cons

Wirgin I, Maceda L, Grunwald C, King TL (2015) Population origin of Atlantic sturgeon Acipenser oxyrinchus oxyrinchus by-catch in U.S. Atlantic coast fisheries. J Fish Biol, 86, 1251-1270.

Wozney KM, Haxton TJ, Kjartanson S, Wilson CC (2010) Genetic assessment of lake sturgeon (Acipenser fulvescens) population structure in the Ottawa River. Env Biol Fish, 90, 183-195.

Zane L, Patarnello T, LUDWIG A, Fontana F, Congiu L (2002) Isolation and characterization of microsatellites in the Adriatic sturgeon (Acipenser naccarii). Mol Ecol Notes, 2, 586-588.

Zeng Q, Ye H, Ludwig A, Wang Z, Zhang Y, Peng Z (2013) Microsatellite development for the endangered Yangtze sturgeon (Acipenser dabryanus Duméril, 1869) using 454 sequencing. J Applchthyol, 29, 1219-1221.

Zhu B, Liao X, Shao Z, Rosenthal H, Chang J (2005) Isolation and characterization of microsatellites in Chinese sturgeon, Acipenser sinensis. Mol Ecol Notes, 5, 888-892. 


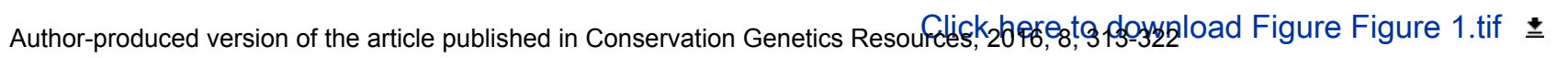
The original publication is available at http://link.springer.com doi : 10.1007/s12686-016-0538-7

A)

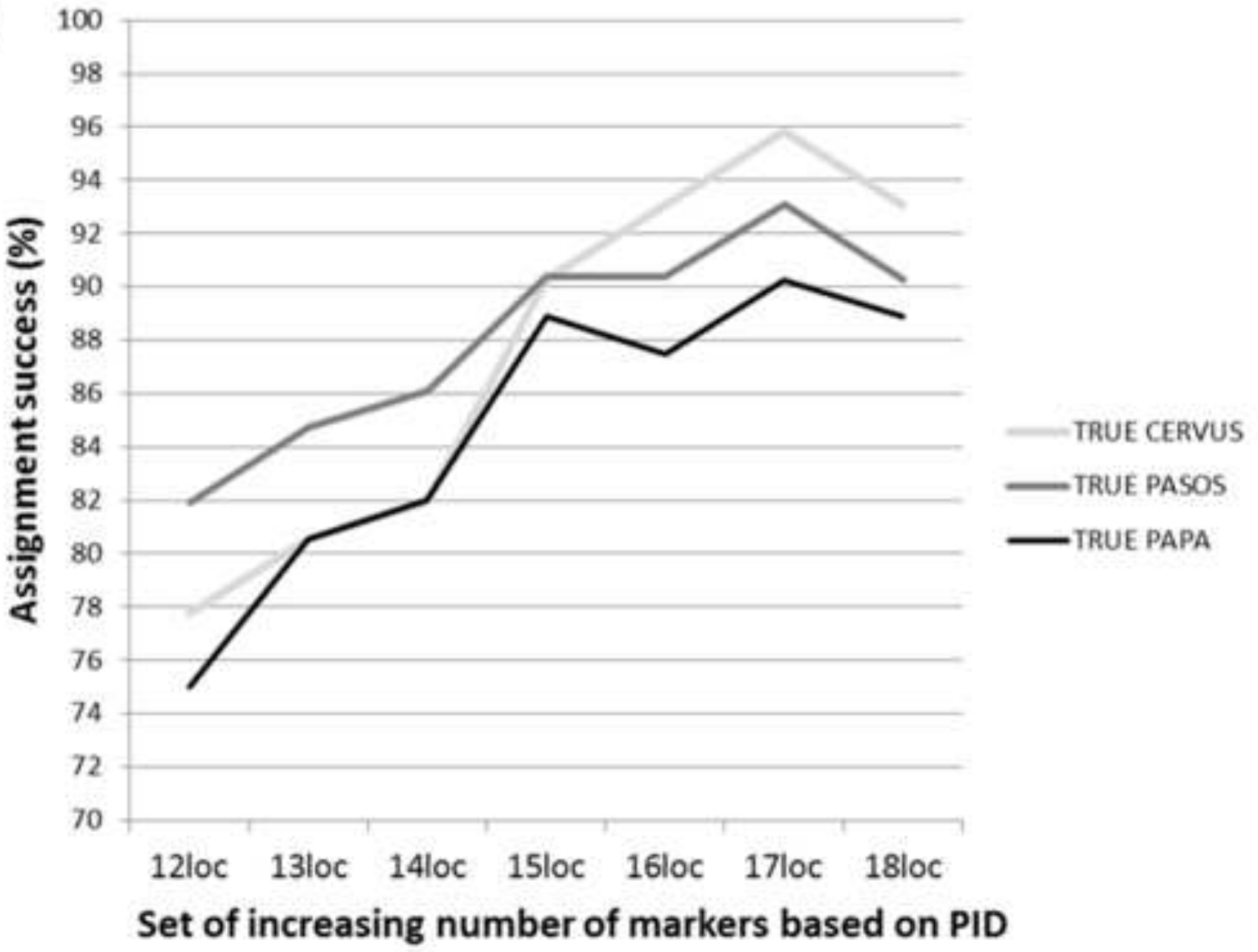

B)

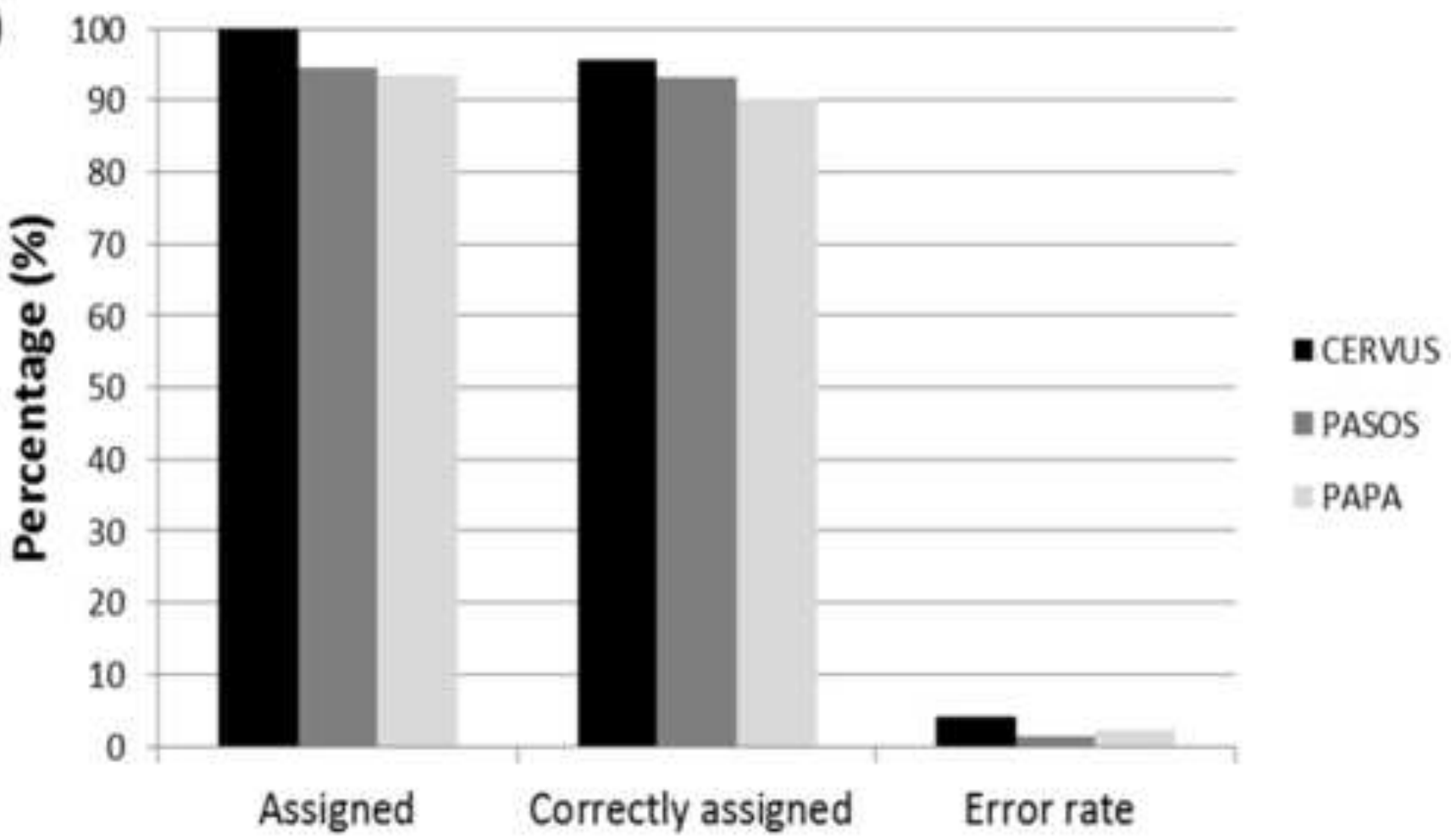


Table 1: 18 microsatellites selected for Acipenser sturio multiplex assay and diversity in $N=51$ Annealing temperature (Ta),fForward ( $F^{*}$, labelled with fluorescent dye) and reverse $(R)$ prin estimates ( $F$ null), rates of amplification success (in percentage), expected (Hexp) and obser

\begin{tabular}{lllll}
\hline Name & Fluorescent dye & MLPX & Ta $(\mathbf{o C})$ & \multicolumn{1}{c}{ Primer sequence $\mathbf{F}^{*} \mathbf{( 5}^{\prime} \mathbf{- \mathbf { 3 } ^ { \prime } )}$} \\
\hline AOXD64 & FAM & MPLX1 & 55 & TTGTCCAATAGTTTCCAACGC \\
AOXD165 & FAM & MPLX1 & 55 & TTTGACAGCTCCTAAGTGATACC \\
AG10 & FAM & MPLX1 & 55 & AACAAGTTCTACCTCGATTTTGG \\
AG47 & NED & MPLX1 & 55 & GCGAAACGACTCCCTTAACA \\
AOXD32 & NED & MPLX1 & 55 & CAGATTTAAGTAAGATAAGCATCAGC \\
AOXD44 & HEX & MPLX1 & 55 & ACCGAGTTTCAAATCAAATAGC \\
AOXD234 & HEX & MPLX1 & 55 & AACTGGCTTTGTGATTGATCC \\
AG14 & FAM & MPLX2 & 55 & GCTGTCCCATTAGCTGATCC \\
AOXD188 & FAM & MPLX2 & 55 & TGAAGTCATTGGTGATGTGTATG \\
AOXC55 & NED & MPLX2 & 55 & GCAAGGTGTATTAAACTGGACC \\
AOXD161 & HEX & MPLX2 & 55 & GTTTGAAATGATTGAGAAAATGC \\
AOX45 & HEX & MPLX2 & 55 & TTTGTGTAGGGAAATACCCTTG \\
AG38 & FAM & MPLX3 & 55 & AAACAGGTATAAAAATGTTGCTTGTG \\
SPL106 & FAM & MPLX3 & 55 & CACGTGGATGCGAGAAATAC \\
AG28 & NED & MPLX3 & 55 & CCATCAGCAGCTTCAACTCA \\
AG39 & HEX & MPLX3 & 55 & CATCTGGGAAGCAAGTGGAG \\
AFU68 & HEX & MPLX3 & 55 & TTATTGCATGGTGTAGCTAAAC \\
AN20 & HEX & MPLX3 & 55 & AATAACAATCATTACATGAGGCT \\
Overall mean & & & & \\
\hline
\end{tabular}


0 captive individuals. Microsatellites are amplified in three multiplex (MLPX1, MLPX2, MLPX3); ier sequences; Number of alleles per locus (A), allelic range in bps (range, bp), null allele freque ved (Hobs) heterozygosity and probabilty of identity under unrelated (PID unrel) and sibling (PII

\begin{tabular}{|c|c|c|c|c|c|}
\hline Primer sequence $R\left(5^{\prime}-3^{\prime}\right)$ & $\mathbf{A}$ & Range (bp) & $F$ (null) & $\begin{array}{l}\text { Amplification } \\
\text { success rate (\%) }\end{array}$ & Hobs \\
\hline TGTGCTCCTGCTTTTACTGTC & 5 & $103-145$ & -0.126 & 99.7 & 0.58 \\
\hline AAAGCCCTACAACAAATGTCAC & 4 & $174-190$ & -0.072 & 100 & 0.73 \\
\hline GAGATTTGAACAAGACAGGAGGA & 7 & $227-287$ & -0.075 & 97.2 & 0.80 \\
\hline ACAGGTCTTGGGCTTTCCTC & 6 & $110-122$ & -0.126 & 100 & 0.59 \\
\hline AAAGCAGCTTTACATAACGG & 4 & $156-204$ & -0.098 & 98.9 & 0.70 \\
\hline TGAAACTGCTGTGCAATAAGAG & 3 & $144-160$ & -0.044 & 100 & 0.60 \\
\hline TGAAGCAAAGGGTATTATTTGAG & 4 & $197-221$ & -0.111 & 97.9 & 0.60 \\
\hline GACAGAGGATGTTTCTGTGAGC & 5 & $188-204$ & -0.167 & 100 & 0.70 \\
\hline ATGGAAATGTTTTATGGTAATGTG & 3 & $244-252$ & 0.049 & 99.7 & 0.57 \\
\hline CGACCCTGTAAAGGAGTAAGC & 4 & $117-141$ & -0.023 & 100 & 0.67 \\
\hline TGAGACAGACACTCTAGTTAAACAGC & 5 & $157-173$ & -0.114 & 100 & 0.72 \\
\hline TGAGTGCAGCCCTACTGCTC & 4 & $198-222$ & -0.037 & 98.9 & 0.42 \\
\hline TCAGAAAGAGTTTAGTACGCATGG & 5 & $190-202$ & -0.087 & 99.3 & 0.59 \\
\hline GGGGAGAAAACTGGGGTAAA & 3 & $227-235$ & -0.002 & 99.7 & 0.51 \\
\hline ACATGCACGTATGCACGC & 5 & $152-172$ & -0.105 & 96.6 & 0.44 \\
\hline CTCGATGGAACCCAGAAAAG & 2 & $123-125$ & -0.183 & 99.7 & 0.47 \\
\hline AGCCCAACACAGACAATATC & 4 & $142-168$ & -0.138 & 99.3 & 0.48 \\
\hline \multirow[t]{2}{*}{ TGGTCAGTTGTTTTTTTTATTGAT } & 5 & $186-214$ & -0.168 & 99.7 & 0.47 \\
\hline & 4 & & & 99.2 & 0.57 \\
\hline
\end{tabular}


ncy

D sibs) scenarios .

\begin{tabular}{llll}
\hline Hexp & PID unrel & PID sibs & References \\
\hline 0.60 & $1.21 \mathrm{E}-08$ & $3.92 \mathrm{E}-04$ & Henderson-Arzapalo and King 2002 \\
0.80 & $8.74 \mathrm{E}-03$ & $1.54 \mathrm{E}-01$ & Henderson-Arzapalo and King 2002 \\
0.90 & $7.00 \mathrm{E}-02$ & $3.69 \mathrm{E}-01$ & Rajkov et al. 2014 \\
0.72 & $9.21 \mathrm{E}-07$ & $2.91 \mathrm{E}-03$ & Rajkov et al. 2014 \\
0.74 & $2.48 \mathrm{E}-05$ & $1.25 \mathrm{E}-02$ & Henderson-Arzapalo and King 2002 \\
0.66 & $5.15 \mathrm{E}-08$ & $7.55 \mathrm{E}-04$ & Henderson-Arzapalo and King 2002 \\
0.68 & $2.17 \mathrm{E}-07$ & $1.48 \mathrm{E}-03$ & Henderson-Arzapalo and King 2002 \\
0.90 & $1.66 \mathrm{E}-04$ & $2.84 \mathrm{E}-02$ & Rajkov et al. 2014 \\
0.50 & $8.75 \mathrm{E}-10$ & $1.10 \mathrm{E}-04$ & Henderson-Arzapalo and King 2002 \\
0.70 & $4.45 \mathrm{E}-06$ & $5.77 \mathrm{E}-03$ & Henderson-Arzapalo and King 2002 \\
0.88 & $1.14 \mathrm{E}-03$ & $6.52 \mathrm{E}-02$ & Henderson-Arzapalo and King 2002 \\
0.52 & $1.88 \mathrm{E}-12$ & $5.53 \mathrm{E}-06$ & Henderson-Arzapalo and King 2002 \\
0.72 & $3.10 \mathrm{E}-09$ & $2.04 \mathrm{E}-04$ & Rajkov et al. 2014 \\
0.54 & $3.01 \mathrm{E}-10$ & $6.39 \mathrm{E}-05$ & McQuown et al. 2005 \\
0.46 & $1.29 \mathrm{E}-11$ & $1.42 \mathrm{E}-05$ & Rajkov et al. 2014 \\
0.66 & $5.06 \mathrm{E}-12$ & $8.74 \mathrm{E}-06$ & Rajkov et al. 2014 \\
0.64 & $1.06 \mathrm{E}-10$ & $3.82 \mathrm{E}-05$ & Welsch et al. 2003 \\
0.62 & $3.83 \mathrm{E}-11$ & $2.32 \mathrm{E}-05$ & Zane et al. 2002 \\
$\mathbf{0 . 6 5}$ & $\mathbf{1 . 8 8 E - 1 2}$ & $\mathbf{5 . 5 3 E - 0 6}$ & \\
\hline & & & \\
\hline
\end{tabular}




\section{Appendix 1: List of 118 sturgeon loci tested in this study}

POLYM: positivie amplification and more than one allele per locus, UNCLI SIZE: Size exceeding 500 bps; NO AMP: no amplification

\begin{tabular}{|c|c|c|}
\hline Locus & Amplification & Species \\
\hline AfuG113 & POLYM & Acipenser fulvescens \\
\hline $\mathrm{Ag} 01$ & UNCLEAR & Acipenser gueldenstaedtii \\
\hline $\operatorname{Ag} 12$ & DUPLI & Acipenser gueldenstaedtii \\
\hline $\mathrm{Ag} 15$ & DUPLI & Acipenser gueldenstaedtii \\
\hline AoxB34 & POLYM & Acipenser oxyrinchus \\
\hline AoxD241 & POLYM & Acipenser oxyrinchus \\
\hline AciG22 & UNCLEAR & Acipenser transmontanus/Acipenser mer \\
\hline AfuG198 & MONOM & Acipenser fulvescens \\
\hline Afug51 & MONOM & Acipenser fulvescens \\
\hline Ag02 & MONOM & Acipenser gueldenstaedtii \\
\hline $\mathrm{Ag08}$ & MONOM & Acipenser gueldenstaedtii \\
\hline Ag09 & MONOM & Acipenser gueldenstaedtii \\
\hline $\operatorname{Ag} 19$ & MONOM & Acipenser gueldenstaedtii \\
\hline $\operatorname{Ag} 21$ & MONOM & Acipenser gueldenstaedtii \\
\hline Ag22 & MONOM & Acipenser gueldenstaedtii \\
\hline $\mathrm{Ag} 24$ & MONOM & Acipenser gueldenstaedtii \\
\hline $\operatorname{Ag} 25$ & MONOM & Acipenser gueldenstaedtii \\
\hline Ag26 & MONOM & Acipenser gueldenstaedtii \\
\hline Ag35 & MONOM & Acipenser gueldenstaedtii \\
\hline $\mathrm{Ag} 40$ & MONOM & Acipenser gueldenstaedtii \\
\hline $\mathrm{Ag} 45$ & MONOM & Acipenser gueldenstaedtii \\
\hline AoxD242 & MONOM & Acipenser oxyrinchus \\
\hline AS004 & MONOM & Acipenser sinensis \\
\hline AS021 & MONOM & Acipenser sinensis \\
\hline AS043 & MONOM & Acipenser sinensis \\
\hline Psp-26 & MONOM & Polyodon spathula \\
\hline Psp-29 & MONOM & Polyodon spathula \\
\hline Spl-163 & MONOM & Scaphirhynchus platorynchus \\
\hline AciG 56 & NO AMP & Acipenser transmontanus/Acipenser mer \\
\hline AciG 93 & NO AMP & Acipenser transmontanus/Acipenser mer \\
\hline AciG110 & NO AMP & Acipenser transmontanus/Acipenser mer \\
\hline AciG142 & NO AMP & Acipenser transmontanus/Acipenser mer \\
\hline AciG48 & NO AMP & Acipenser transmontanus/Acipenser mer \\
\hline AciG4 & NO AMP & Acipenser transmontanus/Acipenser mer \\
\hline AciG76 & NO AMP & Acipenser transmontanus/Acipenser mer \\
\hline AfuG115 & NO AMP & Acipenser fulvescens \\
\hline $\mathrm{Ag03}$ & NO AMP & Acipenser gueldenstaedtii \\
\hline $\mathrm{Ag04}$ & NO AMP & Acipenser gueldenstaedtii \\
\hline $\mathrm{Ag06}$ & NO AMP & Acipenser gueldenstaedtii \\
\hline $\mathrm{Ag} 07$ & NO AMP & Acipenser gueldenstaedtii \\
\hline $\operatorname{Ag} 17$ & NO AMP & Acipenser gueldenstaedtii \\
\hline $\mathrm{Ag} 18$ & NO AMP & Acipenser gueldenstaedtii \\
\hline
\end{tabular}




\begin{tabular}{|c|c|c|}
\hline Ag27 & NO AMP & Acipenser gueldenstaedtii \\
\hline Ag29 & NO AMP & Acipenser gueldenstaedtii \\
\hline Ag30 & NO AMP & Acipenser gueldenstaedtii \\
\hline Ag32 & NO AMP & Acipenser gueldenstaedtii \\
\hline Ag33 & NO AMP & Acipenser gueldenstaedtii \\
\hline Ag37 & NO AMP & Acipenser gueldenstaedtii \\
\hline Ag42 & NO AMP & Acipenser gueldenstaedtii \\
\hline Ag43 & NO AMP & Acipenser gueldenstaedtii \\
\hline $\mathrm{Ag} 44$ & NO AMP & Acipenser gueldenstaedtii \\
\hline Ag46 & NO AMP & Acipenser gueldenstaedtii \\
\hline Ag50 & NO AMP & Acipenser gueldenstaedtii \\
\hline An16 & NO AMP & Acipenser naccarii \\
\hline AnacE4 & NO AMP & Acipenser naccarii \\
\hline AoxB28 & NO AMP & Acipenser oxyrinchus \\
\hline AoxD170 & NO AMP & Acipenser oxyrinchus \\
\hline LS34 & NO AMP & Acipenser fulvescens \\
\hline Psp-12 & NO AMP & Polyodon spathula \\
\hline Psp-20 & NO AMP & Polyodon spathula \\
\hline Psp-21 & NO AMP & Polyodon spathula \\
\hline Spl-100 & NO AMP & Scaphirhynchus platorynchus \\
\hline Spl-104 & NO AMP & Scaphirhynchus platorynchus \\
\hline Spl123 & NO AMP & Scaphirhynchus platorynchus \\
\hline Spl-168 & NO AMP & Scaphirhynchus platorynchus \\
\hline Spl170a & NO AMP & Scaphirhynchus platorynchus \\
\hline AfuG123 & UNCLEAR & Acipenser fulvescens \\
\hline AfuG72 & UNCLEAR & Acipenser fulvescens \\
\hline Ag05 & UNCLEAR & Acipenser gueldenstaedtii \\
\hline $\operatorname{Ag} 13$ & UNCLEAR & Acipenser gueldenstaedtii \\
\hline Ag36 & UNCLEAR & Acipenser gueldenstaedtii \\
\hline Ag41 & UNCLEAR & Acipenser gueldenstaedtii \\
\hline Ag48 & UNCLEAR & Acipenser gueldenstaedtii \\
\hline Ag49 & UNCLEAR & Acipenser gueldenstaedtii \\
\hline AnacC11 & UNCLEAR & Acipenser naccarii \\
\hline AnacD3 & UNCLEAR & Acipenser naccarii \\
\hline Aox12 & UNCLEAR & Acipenser oxyrinchus \\
\hline AoxD161 & POLYM & Acipenser oxyrinchus \\
\hline AoxD242 & UNCLEAR & Acipenser oxyrinchus \\
\hline AciG198 & POLYM & Acipenser transmontanus/Acipenser meı \\
\hline Afu19 & POLYM & Acipenser fulvescens \\
\hline Afu39 & UNCLEAR & Acipenser fulvescens \\
\hline Afu54 & POLYM & Acipenser fulvescens \\
\hline Afu68 & POLYM & Acipenser fulvescens \\
\hline AfuG184 & POLYM & Acipenser fulvescens \\
\hline Afug41 & UNCLEAR & Acipenser fulvescens \\
\hline Ag10 & POLYM & Acipenser gueldenstaedtii \\
\hline $\mathrm{Ag} 14$ & POLYM & Acipenser gueldenstaedtii \\
\hline Ag16 & POLYM & Acipenser gueldenstaedtii \\
\hline Ag20 & POLYM & Acipenser gueldenstaedtii \\
\hline
\end{tabular}




\begin{tabular}{lll} 
Ag28 & POLYM & Acipenser gueldenstaedtii \\
Ag31 & UNCLEAR & Acipenser gueldenstaedtii \\
Ag38 & POLYM & Acipenser gueldenstaedtii \\
Ag39 & POLYM & Acipenser gueldenstaedtii \\
Ag47 & POLYM & Acipenser gueldenstaedtii \\
An20 & POLYM & Acipenser naccarii \\
Aox23 & POLYM & Acipenser oxyrinchus \\
Aox27 & POLYM & Acipenser oxyrinchus \\
Aox45 & POLYM & Acipenser oxyrinchus \\
AoxC55 & POLYM & Acipenser oxyrinchus \\
AoxD165 & POLYM & Acipenser oxyrinchus \\
AoxD172 & UNCLEAR & Acipenser oxyrinchus \\
AoxD188 & POLYM & Acipenser oxyrinchus \\
AoxD242 & MONOM & Acipenser oxyrinchus \\
AoxD234 & POLYM & Acipenser oxyrinchus \\
AoxD297 & POLYM & Acipenser oxyrinchus \\
AoxD32 & POLYM & Acipenser oxyrinchus \\
AoxD44 & POLYM & Acipenser oxyrinchus \\
AoxD54 & POLYM & Acipenser oxyrinchus \\
AoxD64 & POLYM & Acipenser oxyrinchus \\
AS002 & POLYM & Acipenser sinensis \\
Spl101 & POLYM & Scaphirhynchus platorynchus \\
Spl-106 & POLYM & Scaphirhynchus platorynchus \\
Spl-113 & UNCLEAR & Scaphirhynchus platorynchus \\
Ag11 & SIZE & Acipenser gueldenstaedtii \\
Ag23 & SIZE & Acipenser gueldenstaedtii \\
Ag34 & SIZE & Acipenser gueldenstaedtii \\
An77 & SIZE & Acipenser naccarii \\
\hline & &
\end{tabular}

